\title{
KEPEMIMPINAN PEMERINTAH DESA DALAM PERCEPATAN PEMBANGUNAN PRASARANA WILAYAH PEMEKARAN DI DESA LAMBANAN KECAMATAN LATIMOJONG KABUPATEN LUWU
}

\author{
Fitra ${ }^{1}$, Muhlis Madani ${ }^{2}$ Muhammad Tahir ${ }^{2}$ \\ ${ }^{1}$ Program Studi Ilmu Pemerintahan Fakultas Ilmu Sosial dan Ilmu Politik \\ Universitas Muhammadiyah Makassar \\ Jl. Sultan Alauddin No. 259 Makassar 90221 \\ Telp. 0411-866972 ext.107.Fax.0411-8655888 \\ Fitra0192@yahoo.co.id \\ ${ }_{2}^{2}$ Program Studi Ilmu Administrasi Negara Fakultas Ilmu Sosial dan Ilmu Politik \\ Universitas Muhammadiyah Makassar \\ Jl. Sultan Alauddin No. 259 Makassar 90221 \\ Telp. 0411-866972 ext.107.Fax.0411-8655888 \\ muhlismadani@yahoo.com mtahir@gmail.com
}

\begin{abstract}
This study aims to determine how the village government leadership in implementing the accelerated development of regional infrastructure expansion in the Village District of Latimojong Lambanan Luwu. This type of research used in this research is descriptive qualitative survey research base. Data collection technique used observation, documentation and interview. As for the population in this study is an element Lambanan village government and community leaders in the village of the District Lambanan Latimojong Luwu by sampling using purposive sampling techniques, then the results of the data is analyzed qualitatively. The results showed that although the Village Lambanan a new village bloomed, but the development in the Village Lambanan relatively fast, this is because the business is quite active village head and the support and participation of the communities Lambanan. With a leadership style that is applied by the village head Lambanan that traditional democracy with participatory development concept, simple and populist Village Head Lambanan able to attract sympathy and trust of the community. Because people are targets and perpetrators of development, the Village Head Lambanan always mengikutsertaka communities in the planning and execution of development.
\end{abstract}

Keywords: leadership, accelerated development

\begin{abstract}
ABSTRAK
Penelitian ini bertujuan untuk mengetahui bagaimana kepemimpinan pemerintah desa dalam melaksanakan percepatan pembangunan prasarana wilayah pemekaran di Desa Lambanan Kecamatan Latimojong Kabupaten Luwu. Tipe penelitian yang digunakan dalam penelitian ini adalah deskriptif kualitatif dengan dasar penelitian survey. Teknik pengumpulan data menggunakan observasi, dokumentasi dan wawancara. Adapun yang menjadi populasi dalam penelitian ini adalah unsur pemerintah Desa Lambanan dan Tokoh masyarakat di Desa Lambanan Kecamatan Latimojong Kabupaten Luwu dengan penarikan sampel menggunakan teknik purposive sample, kemudian hasil dari data tersebut di analisa secara kualitatif. Dari hasil penelitian menunjukkan bahwa walaupun Desa Lambanan merupakan desa yang baru dimekarkan, tetapi pembangunan di Desa Lambanan tergolong cepat, hal ini disebabkan karena usaha kepala desa yang cukup aktif dan dukungan serta partisipasi dari masyarakat desa Lambanan. Dengan gaya kepemimpinan yang diterapkan oleh kepala desa Lambanan yaitu demokrasi tradisional dengan Konsep pembangunan partisipatif, sederhana dan merakyat Kepala Desa Lambanan mampu menarik simpati dan kepercayaan dari masyarakat. Karena masyarakat adalah sasaran sekaligus pelaku pembangunan, Kepala Desa Lambanan selalu mengikutsertakan masyarakat dalam setiap perencanaan dan pelaksanaan pembangunan.
\end{abstract}

Kata Kunci : kepemimpinan, percepatan pembangunan 


\section{A. PENDAHULUAN}

Salah satu syarat yang diperlukan untuk menunjukkan tingginya tingkat keberhasilan pembangunan yang dilaksanakan oleh Pemerintah yaitu dimulai dari mantapnya pemahaman dari para aparat terkait tentang makna indikator-indikator dan variable-variabel pembangunan serta pengertian kebijaksanaan yang diterapkan oleh pemerintah pusat dan daerah, dimana kedua kebijaksanaan tersebut harus saling melengkapi ataukan searah. Pemahaman yang memadai tentang indikator pembangunan daerah ini akan mengakibatkan semakin terarahnya pelaksanaan pembangunan yang dilaksanakan dan semakin tingginya responsi masyarakat dalam menyukseskan dan mencapai sasaran yang telah ditargetkan. Hal ini saya anggap perlu mendapatkan perhatian terutama dari pihakpihak pengambilan keputusan, mengingat proses panjang perjalanan bangsa ini untuk mengisi kemerdekaan harus mendapatkan perhatian dari kita semua. Persentase keberadaan Bangsa Indonesia belum beranjak dari starting point pada masa kita memproklamirkan kemerdekaan.

Pembangunan Desa ini sebagai bagian dari Pembangunan Nasional dan daerah, pada dasarnya merupakan keseluruhan upaya dalam rangkaian kegiatan yang dilaksanakan secara berencana oleh Pemerintah dan masyarakat, untuk meningkatkan kesejahteraan masyarakat dari berbagai segala aspek kehidupan baik ekonomi, politik, sosial dan kebudayaan. Oleh arena itu Pemerintah perlu memikirkan program dilaksanakannya program Percepatan Pembangunan Desa karena masih adanya urusan, program dan kegiatan yang ditangani Pemda (SKPD) belum mampu menyentuh seluruh aspirasi dan permasalahan masyarakat khususnya pemenuhan hak-hak dasar. Keterlibatan desa dalam pembangunan (musrenbang desa) masih terbatas mengajukan usulan. Partisipasi dan tanggungjawab pembangunan cenderung rendah dan Informasi program pembangunan kurang transparan. Perlu ada kebijakan daerah untuk meningkatkan pelayanan, pemberdayaan masyarakat, dan partisipasi masyarakat (Percepatan Pembangunan Desa) melalui desentralisasi urusan daerah kepada desa serta pemberian tugas pembantuan.

Luasnya wilayah Desa dengan tingginya jumlah penduduk dapat mengakibatkan pelayanan terhadap masyarakat tidak maksimal oleh pemerintah Desa , sehingga tidak efisien serta lambatnya birokrasi dalam mengantisifasi permasalahn yang timbul dalam pemenuhan tuntutan masyarakat. Dengan kondisi yang demikian bisa mengakibatkan munculnya kerawanan dan kecemburuan sosial dikalangan masyarakat, karena itu salah satu langkah yang diambil oleh pemerintah sebagai pencegahan yaitu pemekaran desa untuk desa yang memang telah memenuhi syarat. Dengan demikian diharapkan pembangunan masingmasing daerah akan lebih merata sehingga dapat lebih maju, mandiri, sejahtera dan kompetitif di dalam pelaksanaan pemerintahan maupun pembangunan.

Berdasarkan latar belakang yang telah dikemukakan, penulis tertarik melakukan penelitian tentang Kepemimpinan Pemerintah Desa Dalam Melaksanakan Percepatan Pembangunan Prasarana Wilayah Pemekaran Di Desa Lambanan Kecamatan Latimojong Kabupaten Luwu. karena tingginya tingkat keberhasilan pembangunan prasarana desa pemekaran dan semakin tingginya responsi masyarakat dalam menyukseskan dan mencapai sasaran yang telah ditargetkan di wilayah pemekaran Desa Lambanan Kecamatan Latimojong Kabupaten Luwu. Untuk membahas lebih lanjut mengenai kepemimpinan dan percepatan pembangunan di Desa Latimojong dengan judul "Kepemimpinan Pemerintah Desa Dalam Melaksanakan Percepatan Pembangunan Prasarana Wilayah Pemekaran".

\section{B. PERCEPATAN PEMBANGUNAN DAERAH}

Pembangunan daerah adalah suatu proses di mana pemerintah daerah dan masyarakatnya mengelola sumberdayasumberdaya yang ada dan membentuk suatu pola kemitraan antara pemerintah daerah dengan sektor swasta untuk menciptakan suatu lapangan kerja baru dan merangsang perkembangan kegiatan ekonomi (pertumbuhan ekonomi) dalam wilayah tersebut. Untuk mendukung proses tersebut 
pemerintah membuat program Percepatan Pembangunan Daerah Tertinggal dan Khusus (P2DTK), yaitu sebuah program uji coba inovatif yang dirintis oleh Pemerintah Indonesia pada bulan Agustus 2005 dan dirancang untuk mengatasi permasalahan pemerintahan dan kebijakan di 51 kabupaten termiskin di seluruh Indonesia. P2DTK didasarkan pada sejumlah proyek pengembangan masyarakat lain yang telah sukses, seperti Program Pengembangan Kecamatan (PPK/KDP), untuk menyelaraskan prosedur perencanaan secara bottom-up dengan pemerintah kabupaten yang baru saja diberdayakan.

\section{TINDAKAN AFIRMATIF TERHADAP KETERTINGGALAN}

Kebijakan pembangunan dan pemerintahan yang sentralistik kemudian berubah menjadi berdasarkan otonomi daerah seiring dengan reformasi. Namun sepuluh tahun reformasi berlalu, otonomi daerah, yang memberikan daerah hak, wewenang dan kewajiban untuk mengatur dan mengurus sendiri urusan pemerintahan, belum berhasil menjawab permasalahan ketertinggalan sejumlah daerah dalam suatu Daerah Otonom. Di sisi lain, reformasi ketatanegaraan telah menjadikan pemilihan kepala daerah berdasarkan pada sistem pemilihan langsung oleh penduduk daerah yang bersangkutan. Namun realita demografi menunjukkan bahwa keterisolasian sejumlah wilayah dalam suatu daerah membuat wilayah tersebut tidak signifikan sebagai kantong suara dalam proses pemilihan kepala daerah, yang sangat menekankan kepraktisan politik belaka. Demikianlah banyak daerah di Indonesia seolah terjebak dalam keterisolasian pembangunan dan politik, dan terus tertinggal.

Kondisi ini harus mendapatkan perhatian yang cermat, serius, dan sesuai dengan dinamika ketatanegaraan serta hukum yang ada, sehingga Negara tidak gagal dalam kewajibannya memenuhi hakhak konstitusional setiap warga negara. Di sisi yang lain, dalam alam kemerdekaan, hak setiap warga negara untuk menjadi sejahtera dan cerdas dalam kerangka
Negara Kesatuan Republik Indonesia (NKRI) tidak boleh terpasung. Dengan mempertimbangkan juga perkembangan regional terutama di Asia Tenggara, maka suatu kebijakan nasional untuk percepatan pembangunan sejumlah daerah tertinggal sebagai suatu tindakan-afirmatif (affirmative action) merupakan suatu langkah strategis yang sudah sangat mendesak.

Tujuan percepatan pembangunan daerah tertinggal adalah untuk:

(1) Memberikan dan menjamin pemenuhan hak dan kesempatan kepada setiap warga negara dan daerah tertinggal untuk mewujudkan keadilan dan kesejahteraan agar setara dengan daerah lainnya dalam wilayah NKRI; (2) Memberdayakan masyarakat daerah tertinggal melalui pembukaan atau peningkatan akses dalam berbagai bidang sehingga mereka mampu menjaga harkat dan martabat sebagaimana warga negara Indonesia lainnya; (3) Meningkatkan kualitas sumber daya manusia melalui pemenuhan kebutuhan dasar masyarakat, termasuk namun tidak terbatas pada kesehatan, pendidikan, dan lapangan pekerjaan; (4) Meningkatkan ketersediaan sarana dan prasarana di dalam daerah tertinggal, antara lain energi (listrik), transportasi, telekomunikasi, dan sarana perdagangan; dan (5) Mempercepat terciptanya keseimbangan pembangunan daerah tertinggal dengan daerah lainnya, sehingga terjadi harmonisasi kehidupan antarmasyarakat.

\section{PEMBANGUNAN DAERAH}

Usaha percepatan pembangunan daerah tertinggal tunduk pada Pasal 18B ayat 2 UUD 1945, yakni "Negara mengakui dan menghormati kesatuan-kesatuan masyarakat hukum adat beserta hak-hak tradisionalnya 
sepanjang masih hidup dan sesuai dengan perkembangan masyarakat dan prinsip Negara Kesatuan Republik Indonesia, yang diatur dalam undang-undang." Pengakuan dan penghormatan ini penting, paling tidak untuk dua hal. Pertama, percepatan pembangunan bukanlah untuk mengeksploitasi sumber daya alam daerah bersangkutan, tapi memberikan hak yang sama kepada setiap warga negara untuk maju dan berkembang dalam kerangka NKRI. Oleh karena itu, masyarakat hukum adat dan hak-hak tradisionalnya tidak boleh terkooptasi oleh pembangunan, apalagi termarjinalkan. Kedua, budaya dan adat di Indonesia demikian beraneka ragam dan tidak semua masyarakat hukum adat memiliki orientasi dan penerimaan yang sama tentang pembangunan. Sebagian menerima pembangunan, sementara sebagian lain memutuskan untuk meneruskan pola kehidupan yang ajeg dan memilih untuk tidak ikut menerima pembangunan.

\section{E. METODE PENELITIAN}

Penelitian dilakukan di Desa Lambanan Kecamatan Latimojong, Kabupaten Luwu. Desa Lambanan sebelumnya adalah bagian dari wilayah Desa Latimojong yang meliputi : Dusun Tibussan, Dusun Doke-doke, Dusun Lambanan, Dusun Tiroweli, dan Dusun Cambaleko. Penelitian akan dilakukan selama 2 bulan untuk memperoleh data yang diperlukan oleh peneliti.Jenis data yang digunakan dalam penelitian ini adalah ini adalah data deskriptif kualitatif.Data primer merupakan data yang bersumber dari informan langsung dan diperoleh dari hasil wawancara dengan informan.Data sekunder adalah data yang diperoleh dari sumber kedua atau sumber sekunder dari data yang kita butuhkan yang digunakan untuk menjelaskan data primer. Sumber data sekunder diharapkan dapat berperan membantu mangungkap data yang diharapkan atau permasalahan yang diteliti seperti buku-buku literatur, jurnal majalah atau Koran, dsb. Informan dalam penelitian ini antara lain : Camat Latimojong, Kepala
Desa Latimojong, Kepala Desa Lambanan, Ketua BPD Lambanan, Aparat Desa Lambanan, Kepala Dusun yang ada di Desa Lambanan, Tokoh Masyarakat, dan Masyarakat setempat.

Teknik pengambilan sasaran penelitian ini merupakan metode memilih atau menetapkan sasaran penelitian berdasarkan pertimbangan-pertimbangan tertentu tanpa mendasarkan dari resistensi atau keterwakilan dari populasi tetapi lebih mengarah pada cakupan, kekhasan dan kedalaman informasi yang dianggap tahu dan dapat dipercaya untuk menjadi sumber yang kompeten dan dapat memberikan informasi yang dibutuhkan oleh peneliti. Observasi, Wawancara mendalam dengan menggunakan pedoman wawancara (interview), Dokumentasi, Metode analisis data dalam penelitian ini adalah analisis deskriptif kualitatif, dengan model analisis interaktif.

\section{F. HASIL DAN PEMBAHASAN}

Gaya kepemimpinan yang diterapkan Kepala Desa Lambanan tergolong gaya demokrasi tradisional. Dengan gaya demokrasinya, Kepala Desa Lambanan selalu melibatkan masyarakatnya dalam setiap kegiatan pembangunan sehingga bisa mendapatkan kepercayaan dari masyarakat. Hal di atas senada dengan hasil wawancara peneliti dengan Bapak Kepala Desa Lambanan, berikut ini.
"perkembangan pembangunan di Desa Lambanan bukan semata-mata karena saya, tetapi juga karena masyarakat Desa Lambanan memiliki persatuan, persaudaraan dan kerjasama yang cukup baik serta tingkat kesadaran yang tinggi akan pentingnya suatu pembangunan. Yang saya lakukan untuk desa ini hanya sesuai dengan posisi saya yaitu sebagai pelayan dan fasilitator masyarakat. (wawancara, BUR)

Dari hasil wawancara di atas dapat ditarik kesimpulan bahwa kepala desa berfungsi sebagai fasilitator dan masyrakat sebagai penggeraknya, sehingga peran serta masyarakat sangat dibutuhkan dalam pembangunan dengan kata lain kedua hal ini 
saling membutuhkan karena fasilitator tanpa penggerak tidak akan berjalan dan sebaliknya penggerak anpa fasilitator idak akan mengahasilkan apa-apa. Dengan gaya kepemimpinan yang tepat dari kepala Desa Lambanan da semangat gotong royong dari masyarakatnya serta persatuan, persaudaraan dan kerjasama yang baik, maka tidaklah mengherankan jika laju pembangunan di Desa Lambanan berkembang cukup pesat. Hal ini dapat dilihat dari pencapaian rencana pembangunan desa dalam hal sarana dan prasarana desa.

Kepala desa dalam mengambil sebuah kebijakan, beliau juga melihat dari berbagai aspek kehidupan dan sudut pandang sehingga keputusan yang dia ambil pun bijaksana demi terwujudnya tujuan bersama maka secara tidak langsung kewibawaan tersebut akan terpancar dalam diri seorang pemimpin. Sebagai seorang kepala desa, sekaligus pemimpin dalam pemerintahan desa maka seorang kepala desa harus mempunyai jiwa pemimpin, mampu dan mau bekerja sama dengan para perangkat desa yang lainnya maupun dangan aparat pemerintah lain di atasnya dalam menjalankan tugas dan kewajibannya, mengingat fungsinya dalam pembangunan yaitu :
a. Sebagai stabilisator
b. Sebagai inovator
c. Sebagai pelopor

Kewibawaan seorang pemimpin tidak hanya ketika dalam mengambil keputusan, tetapi dapat juga dilihat dari bagaimana seorang pemimpin dapat mengendalikan dirinya terutama dalam mengendalikan emosinya di setiap penyelesaian masalah. Hal ini juga yang dilakukan oleh Kepala Desa Lambanan dimana kewibawaannya terpancar dari kesederhanaan dan sikapnya yang mampu memposisikan diri. Hal ini di ungkapkan oleh seorang tokoh masyarakat Desa Lambanan, berikut ini.

Kepala desa itu seorang pemimpin yang dikenal dekat dengan rakyatnya. Dia juga dikenal sebagai sosok pemimpin yang ramah dan peduli terhadap masyarakatnya, dekat dengan pemuda-pemuda desa. tapi kedekatan dan keakraban dengan masyarakatnya tidak berarti beliau kehilangan wibawa. Pak Kepala Desa adalah tipe orang yang pandai bergaul dan pandai menempatkan diri. Walaupun dia adalah seorang pemimpin di desa ini, tapi saat berbicara dengan orang yang lebih tua darinya beliau sangat sopan dan santun dalam berbicara, jadi tak heran jika beliau sangat disukai oleh masyarakat.(wawancara, UCA)

Hal senada juga diungkapkan oleh Seketaris Desa lambanan yang menjadi teman kerja kepala desa dalam memimpin, berikut ini.

Saya sangat senang bekerja sama dengan kepala desa, Bapak adalah sosok pemimpin yang baik dan menurut saya, bisa dikatakan berwibawa, karena dekat dengan masyarakatnya, dan mengikuti normanorma yang ada khususnya dalam memimpin warga dan aparatnya. Beliau juga cerdas dan bijaksana dalam memimpin. Itu dapat terlihat jelas saat ia memimpin rapat, meski bisa dikatakan beliau masih muda tapi pendapat dan nasehat beliau didengarkan oleh semua masyarakat baik itu yang tua maupun pemuda. (wawancara, AGP).

Dari hasil wawancara dengan Bapak Uca sebagai masyarakat Desa Lambanan dan sekertaris Desa lambanan diatas dapat disimpulkan bahwa kepala desa mampu memposisikan dirinya dengan baik. Buktinya dia bisa tetap dekat dengan warganya tanpa harus kehilangan wibawanya sebagai seorang kepala desa. Karena wibawa dan jiwa kepemimpinan yang dimilikinya, walaupun umur yan dimilikinya masih cukup muda tetapi nasehat dan pendapat yang disampaikan oleh beliau bisa diterima oleh masyarakatnya baik yang tua maupun yang muda tanpa merasa digurui ataupun disinggung.

Dengan gaya kepemimpinannya yang 
sederhana dan merakyat, proses pembangunan di Desa Lambanan bisa berjalan dengan lancar. Program kerja utama yang dilakukan pemerintah desa sebagai bentuk dari percepatan pembangunan meliputi pembangunan fisik seperti perbaikan jalan, pengadaan kantor desa, pengadaan SD dan TK, pengerasan jalan peving blok, pembuatan jalan tani, pengadaan air bersih, pengadaan Pusat Kesehatan Desa dan perbaikan rumah ibadah. Pembangunan masyarakat non-fisik seperti sosialisasi tentang pentingnya pendidikan untuk para generasi muda serta memberikan penyuluhan pertanian kepada masyarakat di Desa Lambanan mengingat sebagian besar masyarakat Lambanan bekerja sebagai petani, pembinaan dan pelatihan da'i tingkat desa dan kerja bakti setiap ada program yang membutuhkan swadaya serta gerakan jumat bersih. Program pembangunan yang ada di desa ini sebahagian besar berasal dari ADD, PNPM dan dari pihak swasta. Program pembangunan bertujuan untuk meningkatkan kesejahteraan masyarakat. Pembangunan partisipasi merupakan upaya untuk memberdayakan potensi masyarakat dalam merencanakan pembangunan yang berkaitan dengan potensi sumber daya lokal berdasarkan kajian musyawarah. Hampir setiap kegiatan pembangunan yang dilakukan di Desa Lambanan dilaksanakan melalui musyawarah. Kepala desa selalu melakukan koordinasi dengan perangkat desanya dalam melakukan setiap kegiatan. Selain berkoordinasi dengan bawahannya, kepala desa juga selalu berkoordinasi dengan atasannya seperti camat dan pemerintah daerah.

Hal ini senada dikatakan oleh Camat Latimojong, berikut ini.

Kepala desa memiliki peran yang sangat sentral dalam pembangunan dan pemberdayaan masyarakat, Kepala Desa Lambanan memiliki kinerja yang cukup baik dalam melakukan koordinasi. Kepala desa melaporkan sejauh mana pembangunan telah terlaksana baik itu secara tersurat maupun secara lisan. Apa saja kelemahan dan kendalanya untuk dievalusi kembali dan dilaporkan ketingkat selanjutnya. (wawancara, MIP)

Dari statement Camat Latimojong dapat ditarik kesimpulan bahwa salah satu faktor pendukung dalam pembangunan adalah koordinasi yang baik antara pemerintah desa khususnya kepala desa dengan pihak kecamatan yang berkelanjutan ke pihak kabupaten. Hal inilah yan senantiasa dilakukan oleh bapak kepala Desa Lambanan untuk memperoleh dukungan dan kepercayaan dari pihak kecamatan dalam hal peningkatan mutu pembangunan di Desa Lambanan.

Pada dasarnya pembangunan desa merupakan tanggung jawab bersama antara pemerintah dan masyarakat. Dalam hal ini masyarakat adalah sasaran sekaligus pelaku pembangunan. Keterlibatan masyarakat pada setiap pembangunan di desa merupakan kunci keberhasilan pembangunan.

Kepala desa mengkoordinasikan pembangunan secara partisipatif melalui organisasi yang ada di desa, sehingga komunikasi antara aparat pemerintah dengan warganya dapat terjalin melalui organisasi desa. Sebagai desa agraris, Desa Lambanan memiliki organisasi kelompok tani di setiap dusunnya agar dapat mewadahi petani dalam meningkatkan nilai tambah usaha tani dan produksi pertanian. Sehingga setiap kebijakan yang akan diambil oleh kepala desa khususnya dalam hal pertanian selalu dimusyawarahkan terlebih dahulu pada kelompok tani dan tokoh masyarakat.

Kepala Desa Lambanan sendiri selalu mengajak warga masyarakatnya berdiskusi baik itu secara formal maupun non formal. Hal ini beliau lakukan agar merangsang masyarakat desa untuk turut aktif dalam proses pembangunan. Peranan pemerintah sendiri khususnya kepala desa adalah sebagai fasilitator dalam pembangunan. Kepala desa juga tidak pernah membeda-bedakan warganya. Sehingga tidak terjadi kecemburuan antar masyarakat yang akan mengakibatkan pada konflik sosial.

Hal ini diungkapkan oleh salah seorang tokoh masyarakat yang ada di Desa 
Lambanan, berikut ini.

Kepala desa sangat ramah dan peduli terhadap warganya. Beliau juga selalu membantu masyarakat tanpa mengharapkan imbalan, bahkan beliau tak pernah membeda-bedakan masyarakatnya. Beliau selalu mengajak masyarakat di desa Lambanan untuk berdiskusi. (wawancara, SMM).

Menurut statement dari salah satu masyarakat Desa Lambanan, Bapak Semmen dapat diketahui bahwa kepedulian bapak kepala desa Lambanan terhadap warganya patut diacungi jempol. Hal ini diakui oleh seluruh masyarakatnya. Beliau dinilai sangat ramah dan tidak membedabedakan, semua sikap yang dimilikinya membuat bapak kepala desa lambanan menjadi contoh dan teladan yang baik bagi masyarakatnya dan para aparatur desa yang lain.

Sebagai pemimpin di Desa Lambanan, kepala desa membina kehidupan masyarakatnya dengan semangat gotong royong, baik itu dalam kehidupan sehari-hari maupun dalam kegiatan pemberdayaan masyarakat. Sebagai desa yang baru saja dimekarkan, pembangunan tentunya merupakan hal yang sangat penting untuk kesejahteraan masyarakat Desa Lambanan yang sebahagian besar penduduknya berprofesi sebagai seorang petani. Kegaiatan-kegiatan dalam pertanian pun dilakukan secara bergotong-royong, misalnya dalam pembersihan lahan, penanaman dan panen cengkeh, kopi dan lain-lain. Tidak hanya dibidang pertanian, gotong royong juga dilakukan dalam pembangunan prasarana seperti perbaikan jalan, pembuatan TK darurat, turbin penerangan desa, jembatan dan plak dekker.

Hal ini senada diungkapkan oleh salah seorang tokoh masyarakat yang ada di desa ini, berikut ini.

Hampir setiap kegiatan-kegiatan yang ada di desa ini selalu bergotong royong. Salah satu contohnya saat pembersihan lahan, penanaman dan panen cengkeh, kopi, perbaikan jalan dan pengadaan TK darurat, para warga saling bergotong royong. karena warga di sini juga sebagian adalah buruh bangunan, sehingga tidak perlu lagi membayar buruh untuk mengerjakan pembangunan di desa ini, kebanyakan pembangunan di desa ini semuanya dilakukan dengan bergotong-royong sehingga menghemat pengeluaran. (wawancara, IS).

Begitu pula diungkapkan oleh salah seorang petani muda, berikut ini:

Kepala desa selalu mengajak warganya untuk bergotong royong, baik itu membersihkan desa, saat membangun desa, bahkan dalam bertani pun kepala desa beserta warga desa di sini selalu bergotong royong. Salah satu kegiatan gotong royong yang dilakukan di desa ini adalah setiap musim tanam sebelum menanam bibit, selalu dilakukan pemberantasan babi secara bersamasama. Kegiatan ini rutin dilakukan oleh warga desa, sehingga babi dapat berkurang jumlahnya juga agar tidak merusak tanaman para petani. (wawancara, SA)

Dari hasil wawancara diatas dapat disimpulkan bahwa kemampuan kepala Desa Lambanan alam membakar semangat gotong royong masyarakatnya patut diacungi jempol. Dengan gaya kepemimpinan yang dimilikinya disini yaitu partisipatif dimana beliau tidak hanya mengarahkan tetapi juga ikut aktif membaur bersama waganya dalam setiap kegiatan, sehingga masyarakat termotifasi untuk ikut aktif. Dengan ikut aktifnya semua masyarakat maka pekerjaan dapat cepat terselesaikan selain itu biaya pengeluaran juga sedikit berkurang karena tenaga-tenaga terampil juga ikut berpartisipasi seperti buruh bangunan sehingga pengeluaran untuk gaji pekerja bisa dialihkan untuk kepentingan pembangunan yang lain.

Selain meningkatkan semangat gotong royong pada warganya, kepala desa juga melakukan pembinaan kehidupan masyarakat melalui pendekatan keagamaan. 
Hal ini agar kehidupan masyarakat desa terhindar dari perbuatan asusila seperti minum tuak, berjudi, merampok dan perbuatan-pebuatan lainnya yang melanggar norma dan kaidah, mengingat seluruh masyarakat Desa Lambanan adalah penganut agama Islam. Kegiatan pembinaan kehidupan masyarakat melalui pendekatan keagamaan dengan cara memperingati hari besar keagamaan. Pembinaan dengan pendekatan keagamaan dilakukan sejak dini melalui TK/TPA di mesjid-mesjid tiap dusun serta lomba da'i dan MTQ tingkat desa.

Selain itu, kepala desa juga membina kehidupan warganya tidak hanya melalui kegiatan-kegiatan formal tapi juga melalui kegiatan-kegiatan non-formal. Kepala desa senantiasa mengajak warganya berdialog khususnya pemuda-pemuda desa, saling berbincang-bincang dan mengajak warganya untuk berbincang-bincang secara terbuka yang biasanya dilakukan di mesjid ketika selesai sholat, dipinggir jalan atau di tempat gotong royong lainnya.

Hal ini diungkapkan oleh salah seorang warga desa, berikut ini.

Saya sangat senang memiliki kepala desa seperti BUR, beliau sangat ramah dan perhatian terhadap warganya. Beliau juga selalu membantu masyarakat tanpa mengharapkan imbalan, bahkan beliau tak pernah membedabedakan warganya. Beliau selalu mengajak masyarakat di desa ini untuk berdiskusi. Beliau juga dekat dengan warganya, apalagi pemudapemuda desa. Beliau selalu memberikan nasehat dan mengajak masyarakat di desa ini untuk selalu shalat berjamaah di mesjid. (wawancara, IB).

Dari hasil wawancara diatas dapat disimpulakan bahwa gaya kepemimpinan yang digunakan Bapak Kepala Desa Lambanan adalah gaya kepemimpinan demokrasi tradisional dimana bapak kepala desa selalu membantu masyarakat tanpa mengaharapkan imbalan. Dari sifat ramah dan kesederhanaan yang dimilikinya membuat beliau selalu dekat dengan warganya sehingga ia mampu mengetahui apa yang sebenarnya diinginkan oleh masyarakat. Gayanya yang santai warga measa nyaman untuk menyampaikan pendapat dan keluhannya. Selain dalam hal pembangunan, kepala desa juga sanga memperhatikan masalah keagamaan di Desa Lambanan terbukti dengan caranya mengajak semua warganya untuk selalu berjamaah di masjid khususnya waktu maghrib dan isya sehingga beliau memiliki kesempatan untuk berkumpul bersama warganya.

Perekonomian desa sangatlah penting untuk dikelola dan dibina. Efektivitas pengelolaan keuangan desa merupakan tujuan dari Kepala Desa Lambanan. Pemasukan anggaran yang tidak stabil dan belum tergalinya sumber Anggaran Pendapatan dan Belanja (APB) Desa masyarakat Desa Lambanan serta belum adanya badan usaha milik desa merupakan kendala-kendala yang dihadapi oleh kepala desa dalam mengelola keuangan desa.

Melalui ADD dan PNPM perekonomian desa sangat terbantu. Desa dapat menghemat biaya pembangunan, karena desa dapat mengelola sendiri proyek pembangunannya dan hasil-hasilnya dapat dipelihara secara baik demi keberlanjutannya. Misalnya saja perbaikan jalan dengan menggunakan ADD dan PNPM masuk ke dalam APB desa.

Hal senada diungkapkan oleh kaur pembangunan berikut ini.

Salah satu pembangunan desa yang termasuk dalam APB desa dan didanai oleh ADD dan PNPM adalah perbaikan jalan di Desa Lambanan dengan tujuan untuk mempermudah aktifitas masyarakat, pengadaan air bersih, perbaikan rumah ibadah, PLTA untuk penerangan desa dan pengadaan bibit dan pupuk untuk kelompok tani. Karena seluruh kegiatan yang didanai oleh ADD atau alokasi dana desa harus direncanakan, dilaksanakan, dan dievaluasi secara terbuka dengan prinsip dari, oleh, dan untuk masyarakat. (wawancara, SE)

Hal senada diungkapkan oleh Kepala Desa Lambanan, berikut ini. 
Dalam pengelolaan keuangan dan perekonomian desa, saya selaku kepala desa dan pemimpin di desa ini berusaha untuk seefisien mungkin dalam mengelola keuangan desa. Saya juga berusaha untuk transparan dalam mengelola keuangan desa. $A P B$ desa adalah instrusment penting yang sangat menentukan terwujudnya tata pemerintahan yang baik yang ada di Desa Lambanan. Sehingga dalam penyusunan $A P B$ desa saya selalu melibatkan setiap komponen aparatur desa. Karena APB desa merupakan milik masyarakat desa. (wawancara, BUR)

Dari hasil wawancara diata dapat dilihat bahwa bapak kepala desa Lambanan sangat transparan dalam pengelolaan keuangan dan perekonomian desa, tidak hanya itu beliau juga selalu melibatkan aparatur desa dalam penyusunan APB desa. Hal ini memang sangatlah perlu untuk dilakukan mengingat masalah keuangan memang hal yang sangat sensitif dalam pemerintahan. Hal ini dilakkan untuk menghindari kecurigaan dari beberapa pihak terutama masyarakat, ketika kecurigaan mulai timbul maka kepercayaan akan hilang dan nantinya akan berubah menjadi fitnah dan akan menimbulkan masalah yang besar.

APB desa merupakan anggaran pemerintah desa yang diwujudkan dalam bentuk angka, pada hakikatnya APB desa adalah program tahunan. Anggaran desa yang tertuang dalam APB desa merupakan satu kesatuan yang terdiri dari anggaran rutin dan anggaran pembangunan. APB desa ditetapkan dengan keputusan desa untuk setiap tahun anggaran yaitu 1 Januri sampai dengan 31 Desember tahun berikutnya.

Penggunaan ADD Desa Lambanan telah sesuai dengan PP 72 Tahun 2005 pasal 68 ayat 1 huruf C, dimana 30\% dari ADD digunakan untuk biaya operasional pemerintah desa dan BPD sedangkan 70\% digunakan untuk kegiatan pemberdayaan masyarakat desa.

Senada dengan hal di atas, Ketua BPD Desa Lambanan berikut ini:

"BPD selaku pengawas dan penampung aspirasi warga desa dalam pengelolaan perekonomian desa. Penyusunan APB desa didasarkan pada partisipasi masyarakat. Penggunaan ADD juga telah sesuai dengan peraturan perundang-undangan yang ada dimana, 30\% dialokasikan untuk biaya operasional pemerintah desa dan BPD sedangkan $70 \%$ digunakan untuk kegiatan pemberdayaan masyarakat. BPD juga menjalankan fungsinya dalam mengawasi pengelolaan $A D D$, dimana kepala desa selalu melaporkan kondisi keuangan desa setiap 3 bulan. (wawancara, JU).

Dari data diatas dapat dilihat bahwa BPD sangat berperan untuk menampung aspirasi masyarakat dalam pengelolaan perekonomian desa. Karena ADD telah diatur dalam undang-undang, maka BPD berperan untuk mengawasi penggunaan ADD desa oleh pemerintah desa. Pembinaan perekonomian desa dilakukan oleh kepala desa lebih bersifat pada pengelolaan keuangan desa dengan seefisien mungkin. Setiap tiga bulan sekali kepala desa rutin memeriksa buku administrasi keuangan desa dengan tujuan untuk meminimalisir penyimpangan dan agar pengeluaran telah sesuai dengan yang ditetapkan anggaran desa yang kemudian melaporkannya pada BPD.

Pemekaran wilayah Desa Lambanan Kecamatan Latimojong ini pada dasarnya merupakan upaya peningkatan kesejahteraan masyarakat dengan tetap berpedoman pada pertumbuhan ekonomi dengan memperhatikan daya dukung wilayah, baik dari segi aspek pelayanan masyarakat, aspek pemerintahan, aspek sosial ekonomi, dan aspek potensi wilayah yang ada. Dengan adanya pemekaran diharapkan mampu memberikan dampak positif bagi kemajuan masyarakat. Secara umum tujuan pembentukan desa sebagaimana dimaksud dalam Pasal 2 Peraturan Menteri Dalam Negeri Nomor 28 Tahun 2006 adalah bertujuan untuk meningkatkan pelayanan public guna mempercepat terwujudnya kesejahteraan masyarakat. Beberapa alasan masyarakat yang kemudian menjadi tujuan bersama dalam pemekaran Desa Lambanan ini antara lain : 
a. Masyarakat menginginkan pelayanan publik yang lebih baik dan lebih mudah, serta pemerataan pembangunan. Melalui pemerintahan desa yang baru diasumsikan akan lebih dapat memberikan pelayanan yang lebih baik dibandingkan dengan pelayanan melalui pemerintahan desa induk dengan cakupan wilayah pelayanan yang lebih luas. Melalui proses perencanaan pembangunan desa pada skala yang lebih terbatas, maka pelayanan publik dan pemerataan pembangunan sesuai kebutuhan masyarakat akan lebih tersedia,

b. Tujuan ingin mendapatkan dana ADD, dengan adanya pemekaran desa baru tentunya akan mendapatkan dana ADD sendiri, dan akan sangat mendukung kelancaran proses pemerataan pembangunan di segala aspek.

c. Pemekaran desa diharapkan mampu mempercepat pertumbuhan ekonomi penduduk setempat. Dengan dikembangkannya desa baru yang otonom, maka akan memberikan peluang untuk menggali berbagai potensi yang selama ini tidak tergali Penyerapan tenaga kerja secara lebih luas di sektor pemerintahan.

Berdasarkan dari keseluruhan data dan hasil wawancara, dapat dilihat bahwa dengan gaya kepemimpinan yang diterapkan oleh Bapak Burhanuddin, SE sebagai seorang kepala desa sangat tepat dimana beliau bisa mengarahkan warganya untuk selalu ikut aktif dalam kegiatan pembangunan, selain itu beliau juga dapat membaur bersama warganya tanpa menghilangkan wibawanya. Terbukti walaupun Desa Lambanan merupakan desa yang baru dimekarkan, namun pembangunannya sudah cukup berhasil, terbukti dengan sebagian tujuan pemekaran desa oleh masyarakat telah terpenuhi.

Mungkin bukan hal yang mudah sebagai desa baru atau desa yang baru dimekarkan, untuk membangun desanya. Namun dengan persatuan, rasa persaudaraan dan kerjasama yang baik antar masyarakat dengan sesama masyarakat maupun masyarakat dengan seluruh perangkat desa, semua keinginan masyarakat dalam hal pembangunan akan segera tercapai.

\section{G. PENUTUP}

Gaya kepemimpinan diterapkan oleh Kepala Desa Lambanan yaitu demokrasi tradisional dengan Konsep pembangunan partisipatif yang merupakan suatu proses pemberdayaan masyarakat sehingga masyarakat mampu mengidentifikasi kebutuhannya sendiri atau kebutuhan kelompok masyarakat sebagai suatu dasar perencanaan pembangunan. Dengan kesederhanaan yang dimiliki oleh Kepala Desa Lambanan, ia mampu berbaur bersama masyarakat sehingga dia mampu mengetahui apa yang diinginkan masyarakat untuk peningkatan pembangunan dan kesejahteraan masyarakat di desa lambanan.

Pelaksanaan program pembangunan yang ada di Desa Lambanan terbagi atas dua, yakni; (a) Pembangunan fisik antara lain pembangunan sarana dan prasarana yaitu perbaikan jalan, pengadaan kantor desa, pengadaan SD dan TK, pengerasan jalan peving blok, pembuatan jalan tani, pengadaan air bersih, pengadaan PLTA penerangan desa, pengadaan Pusat Kesehatan Desa dan perbaikan rumah ibadah, dan (b). Pembangunan non fisik antara lain sosialisasi tentang pentingnya pendidikan untuk para generasi muda serta memberikan penyuluhan pertanian kepada masyarakat di desa lambanan mengingat sebagian besar masyarakat lambanan bekerja sebagai petani, pembinaan dan pelatihan da'i tingkat desa dan kerja bakti setiap ada program yang membutuhkan swadaya serta gerakan jumat bersih.

\section{DAFTAR PUSTAKA}

Hamidi, Jazim dan Budiman Sinaga. 2005. Pembentukan Peraturan PerundangUndangan dalam Sorotan. Jakarta: PT Tatanusa.

Haris, Syamsudin. 2005. Desentralisasi dan Otonomi Daerah. Jakarta : LIPI Press. 
Kansil, CST. Dan Christine S.T. Kansil. 2008. - Pemerintahan Daerah Indonesia, Hukum Administrasi Daerah. Jakarta : Sinar grafika.

Mardiasmo. 2004. Otonomi dan Manajemen Keuangan Daerah. Yogyakarta : Andi Offset.

Moleong, Lexy. 2002. Metode Penelitian Kualitatif. Bandung : Remaja Rosdakarya.

Sabarno, Hari. 2007. Memadu Otonomi Daerah Menjaga Kesatuan Bangsa. Jakarta : Sinar Gravika.

Sugiyono. 2008. Metode penelitian Kuantitatif Kuailitatif dan $R \& D$. Bandung :Alfabeta.

Supriady Bratakusumah, Dedy dan Dadang Solihin. 2002. Otonomi Penyelenggaraan Pemerintah Daerah. Jakarta : PT Gramedia Pustaka Utama.

Dokumen :

UU No. 32 Tahun 2004 tentang Pemerintahan Daerah. 2004. Jakarta : Departemen Dalam Negeri Republik Indonesia.

Peraturan Menteri Dalam Negeri Nomor 28 Tahun 2006 Tentang Pembentukan, Penghapusan, Penggabungan Desa dan Perubahan Status Desa Menjadi Kelurahan.

Peraturan Pemerintah Republik Indonesia No 72 Tahun 2005 tentang Desa.

Peraturan Daerah Kabupaten Luwu Nomor 42 Tahun 2011 Tentang Pembentukan Desa.

Keputusan Menteri Dalam Negeri dan Otonomi Daerah (Keputusan Mendagri) No.21 Tahun 2001 tentang Teknik Penyusunan dan Materi Muatan Produk-produk Hukum Daerah.
Keputusan Mendagri No.22 Tahun 2001 tentang Bentuk Produkproduk Hukum Daerah.

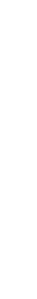

